\title{
Effect of Chilling and Freezing on Fish Muscle
}

\author{
Roopma Gandotra, Shalini Sharma*, Meenakshi Koul and Sweta Gupta \\ Department of Zoology, University of Jammu, Jammu And Kashmir \\ *Email: shalini.shelly17@yahoo.com
}

\begin{abstract}
Muscle samples of Mystus seenghala were stored at two different low temperatures, i.e at $4 \pm I^{\circ} C$ (chilled) and at $-12 \pm 2^{\circ} \mathrm{C}$ (frozen) for 21 days. Weekly analysis was conducted to measure protein, lipid, ash, moisture, free fatty acid, $\mathrm{pH}$ and total plate count. The result clearly reveals that during storage, both the samples showed a highly significant $(p<0.01)$ decreasing trend in protein, lipid, ash and moisture content. After 21 days, the percentage decrease was $54.35 \%$ and $22.70 \%$ for protein and $82.64 \%$ and $56.68 \%$ for lipid, $10.96 \%$ and $4.89 \%$ for moisture and $38.92 \%$ and $37.88 \%$ for ash content in chilled and frozen sample respectively. However, the free fatty acid and $p H$ showed highly significant $(p<0.01)$ increasing trend in both the samples. Similarly, the bacteriological studies revealed that the total plate count (TPC) in chilled and frozen samples also showed an increasing trend. It was found within acceptable limits $(T P C=6.04 \pm 0.11 \mathrm{log} \mathrm{cfu} / \mathrm{g})$ in chilled sample upto $10^{\text {th }}$ day and up to 14th day $(T P C=5.78 \pm 0.2 \log \mathrm{cfu} / \mathrm{g})$ in frozen sample. Thereafter, the microbial quality further deteriorates and became inedible for human consumption.
\end{abstract}

(Keywords: chiller, freezer, spoilage, acceptable limit, inedible.)

\section{Introduction}

Fish has been playing an important role in addressing nutritional and livelihood security of people in the developing countries. Besides, it is good source of polyunsaturated fatty acids (PUFA's), protein, minerals and vitamins which are vital to our health. Although fish is highly nutritious, yet it is one of the most rapid perishable foods because of its short shelf life. The extension of shelf life can be achieved by freezing, chilling, salting, smoking, glazing etc. Consumers usually buy fish in bulk and store in refrigerator. Deterioration of fish quality in refrigerator storage have great impact on the nutritious value of fish and the health of consumers. Considering the importance from consumer view point, this study was designed to study the effect of two different low temperatures $\left(4 \pm 1^{\circ} \mathrm{C}\right.$ and $\left.-12 \pm 2^{\circ} \mathrm{C}\right)$ on fish quality.

\section{Materials And Methods}

Fresh samples of Mystus seenghala were purchased from local market. They were immediately brought to the lab in polythene bags along with crushed ice. The viscera of fish were removed; the fish was washed with water and cut into pieces. These pieces were washed and immediately wrapped in aluminium foil, kept in air tight plastic container and stored at $4 \pm 1{ }^{\circ} \mathrm{C}$ (chilled storage) and at $-12 \pm 2^{\circ} \mathrm{C}$ (frozen storage). Analytical procedures for biochemical and microbiological changes were done on $0,7^{\text {th }}, 14^{\text {th }}$ and $21^{\text {st }}$ day of storage.

\subsection{Biochemical composition:-}

- Moisture content was measured by using hot air oven and aluminium moisture dishes.

- Ash content was measured by using Muffle furnace,

- Total lipid content was estimated by the method of Folch et al. (1957).

- Total protein content was estimated by following the method of Lowry et al. (1951).

- $\quad$ pH was measured by the method of Keller et al. (1974) using digital pH meter.

- Free fatty acid was determined by method of US Army laboratories (Natick) described by Koniecko (1979).

\subsection{Bacteriological Profile}

Total plate count (TPC) in the fish muscle was determined by method described by APHA (1984). Readymade media (Hi-media) were used for the analysis. Serial ten-fold dilutions were made for inoculation. The sample preparation was done near flame under laminar flow.

\subsection{Statistical Analysis}

Means and standard errors were calculated for different parameters, the data analysis was performed using SPSS software. Differences between treatments were analysed by using independent measures one way ANOVA. Post-hoc comparisons were conducted using Ducan's test. The values were expressed as mean \pm SE. $p$ value $<0.05$ were considered as significant and $p$ value $<0.001$ were considered as highly significant. 


\subsection{Total Protein Content}

\section{Result and Discussion:}

At $4 \pm 1^{0} \mathrm{C}$, the initial value of total protein content of muscle of Mystus seenghala was found to be $18.01 \pm 0.06 \%$ and on $21^{\text {st }}$ day this value was found to be least i.e. $8.22 \pm 0.2 \%$. At $-12 \pm 2^{0} \mathrm{C}$, it was found to be $18.81 \pm 0.06 \%$ on the first day of frozen storage and on the last day i.e., $21^{\text {st }}$ day of experimentation the value was further decreased to $14.54 \pm 0.04 \%$. The overall decreased was found to be highly significant ( $\mathrm{p} \leq 0.01)$. In present investigation, decreasing trend was observed. In chilled sample, there was 54.35\% decrease, whereas in frozen samples, there was $22.70 \%$ decrease after $21^{\text {st }}$ day of storage. The present results were found to be in line with those of Kandeepan and Biswas (2007). They found 23\% decrease in total protein content of buffalo meat at $4 \pm 1^{\circ} \mathrm{C}$ (Chilled Storage) and 3.5\% decrease at $-10 \pm 1^{\circ} \mathrm{C}$ (Frozen Storage) after 7 days. According to them, the lower protein content of chilled meat at $4 \pm 1^{\circ} \mathrm{C}$ was due to increased microbial growth resulted from higher water activity $\left(\mathrm{a}_{\mathrm{w}}\right)$ and enzymatic autolysis and on frozen storage the protein content was decreased due to protein denaturation and proteolysis induced by enzymatic activities of psychrotrophic microbial growth. Siddique and Ali (1979) attributed the decrease in protein content of prawn during ice storage to the leaching effect of the amino acids and water soluble proteins leaching out with melting ice. Similarly, Kolodjiejska et al. (1987) while working on biochemical changes in fish muscle during low temperature storage found a remarkable rate of denaturation and autolysis of fish protein. Zamir et al. (1998) calculated 21.79\% decrease in total protein content after 7 days of storage of crab meat at $7 \pm 2^{\circ} \mathrm{C}$. Arannilewa et al. (2005) calculated $27.94 \%$ decrease in protein content of Tilapia (Sarotherodun galiaenus) after 60 day of frozen storage. Siddique et al. (2011) while assessing the effect of freezing time on nutritional value of Puntius sophore, $P$. sarana and $P$. gonionotus registered similar trends during the frozen storage at $-5^{0} \mathrm{C}$ of 20 days. They observed $9.44 \%$ decrease in $P$. sophore, $9.94 \%$ decrease in $P$. sarana and $5.34 \%$ in P. gonionotus in protein content during frozen storage of 20 days.

\subsection{Total Lipid Content}

At $4 \pm 1^{0} \mathrm{C}$, the total lipid content was found to be decreased from initial value of $4.84 \pm 0.015 \%$ ( 0 day) to the final value of $0.84 \pm 0.04 \%$ ( $21^{\text {st }}$ day). At $-12 \pm 2^{\circ} \mathrm{C}$, it was estimated to be $4.94 \pm 0.03 \%$ (o day zero) and reaches up to $2.14 \pm 0.06 \%$ ( $21^{\text {st }}$ day). There was $82.64 \%$ decrease in total lipid content when stored at $4 \pm 1^{0} \mathrm{C}$ and when stored at $-12 \pm 2^{\circ} \mathrm{C}$, there was $56.68 \%$ decrease in total lipid content after $21^{\text {st }}$ day. The overall decrease found to be highly significant $(\mathrm{p} \leq 0.01)$. These results get strong support from the findings of Kandeepan and Biswas (2007) who conducted a similar experiment on buffalo meat. They found $47.94 \%$ decrease in chiller $\left(4 \pm 1^{\circ} \mathrm{C}\right)$ and $17.80 \%$ decrease in freezer in total lipid content during the storage period of 7 days. They attributed this marked decrease in chiller to the exposure of strong light, as in display cabinets, which accelerated oxidation of fats causing discoloration. In freezer they extended the storage up to 75 days. During this prolonged storage, the lipid oxidation occurred mainly due to losses in triglyceride fraction. Agnihotri (1988) reported deterioration in meat lipids took place due to intermediary activities of endogenous meat enzymes leading to hydrolysis of fat. Zamir et al. (1998) attributed the loss in lipid of crab meat stored at refrigerator temperature $7 \pm 2^{\circ} \mathrm{C}$ for one week due to the oxidative rancidity. Arannilewa et al. (2005) calculated $25.92 \%$ decrease in total lipid content in Tilapia after storing it in freezer compartment of the refrigerator for 60 days and associated the changes in fat content during frozen storage with the oxidation of fat. Siddique et al. (2011) found that total lipid content decreased during frozen storage of three species of Puntius. They calculated $35.34 \%, 19.24 \%$ and $21.78 \%$ decrease in total lipid content in P. sophore, P. sarana and P. gonionotus respectively.

\subsection{Moisture Content}

At $4 \pm 1^{0} \mathrm{C}$, the initial moisture content in raw fish muscle was $88.64 \pm 0.1 \%$. On the final day of storage, it was observed to be $78.92 \pm 0.02 \%$. At $-12 \pm 2^{0} \mathrm{C}$, the initial moisture content in raw muscle stored in freezer was $88.04 \pm 0.04 \%$ and on $21^{\text {st }}$ day of the storage, the value decreased to $83.03 \pm 0.02 \%$. The overall decrease found to be highly significant $(\mathrm{p} \leq 0.01)$. Here, the percent decrease in moisture content of raw fish stored at $4 \pm 1^{\circ} \mathrm{C}$ was calculated to be $10.96 \%$ decrease on $21^{\text {st }}$ day, while it was calculated to be $4.89 \%$ decrease at $-12 \pm 2^{\circ} \mathrm{C}$. These results are in agreement with those observed by Kandeepan and Biswas (2007), when they stored buffalo meat in chiller and freezer compartment of refrigerator. Here, the percent decrease in moisture loss was found to be $5.11 \%$ in chiller and $1.57 \%$ in freezer after seven days of storage. They advocated that the more decrease in moisture content was due to evaporation of moisture from meat in chiller, whereas the decrease in moisture content was due to sublimation of surface water of the meat in the freezer. In freezer, the storage was extended up to 75 days, the significant moisture losses in later storage periods was due to the myofibrillar distortion resulting in the poor water detention ability of the meat. According to Kirschnik et al. (2006), moisture content was constant for 14 days in samples of tail meat of the giant river prawn, (Macrobrachium rosenbergii) stored without direct contact in ice, while in samples stored in direct contact with ice it increased approximately 6\%, 
revealing absorption of water through exposed surface of meat and decrease in solid content (crude protein) during early stages of storage in ice.

\subsection{Ash Content}

Fish muscle at 0 day of storage at $4 \pm 1^{0} \mathrm{C}$, the ash content was found to be $1.49 \pm 0.09 \%$ and the final value on $21^{\text {st }}$ day was found to be $0.91 \pm 0.03 \%$. At $-12 \pm 2^{0} \mathrm{C}$, it was about $1.61 \pm 0.07 \%$ on day zero and on $21^{\text {st }}$ day it was estimated about $1 \pm 0.02 \%$.

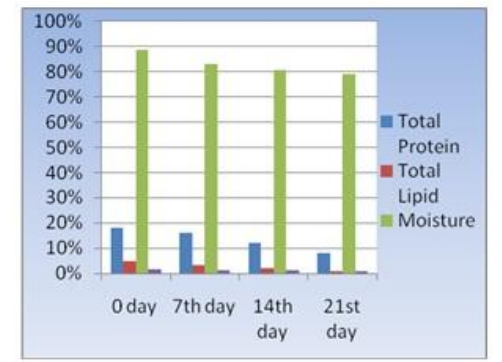

Figure 1: Proximate Composition of Raw Muscle of Figure 2: Proximate Composition of Raw Muscle of Mustus seenghala During Chilled Storage at $4 \pm 1^{\circ} \mathrm{C}$.

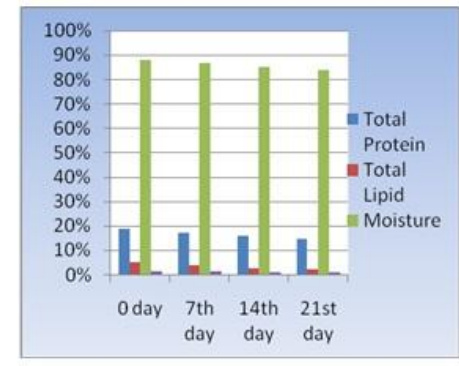

Mystus seenghala During Frozen Storage at $-12 \pm 2^{\circ} \mathrm{C}$.

The overall decrease found to be highly significant ( $p \leq 0.01$ ). Okeyo et. al. (2009) observed that the ash context of the frozen raw Nile perch decreases with storage time. They calculated $12.69 \%$ decrease after 22 days

of ice storage. However, Kandeepan and Biswas (2007) registered 14.87\% decrease in chiller and 20.66\% decrease in freezer after 7 days of storage. According to Arannilewa et al., 2005, the ash content remains almost the same throughout the sixty days frozen storage of Tilapia. It changed from $26.13 \pm 2.20$ (recorded on 0 day) to $26.80 \pm 1.44$ (recorded on $60^{\text {th }}$ day).

\subsection{Free Fatty Acid (FFA)}

At $4 \pm 1^{\circ} \mathrm{C}$ in present studies, it was observed to be $0.5 \pm 0.01 \%$ on day 0 and $12.27 \pm 0.01 \%$ on $21^{\text {st }}$ day. At $-12 \pm 2^{0} \mathrm{C}$, it was $0.57 \pm 0.02 \%$ on day zero and $5.61 \pm 0.05 \%$ on $21^{\text {st }}$ day of storage. Here, more FFA content $(12.27 \pm 0.01 \%)$ was observed in chilled muscle as compared to FFA content $(5.61 \pm 0.05 \%)$ in frozen muscle after 21 days. At $4 \pm 1{ }^{0} \mathrm{C}$, the raw fish sample was found to be near the acceptable limit $(5 \%)$ on $7^{\text {th }}$ day $(4.89 \pm 0.04 \%)$ and at $-12 \pm 2^{0} \mathrm{C}$, the sample crossed the acceptable limit on $21^{\text {st }}$ day $(5.61 \pm 0.05 \%)$. Rodriquez et al. (2007) observed increasing FFA during frozen storage farmed coho salmon (Oncorhynchus kisutch). According to Pacheo-Aguillar et al. (2000) during post mortem period, lipid (glycerol-fatty acids esters) present in the fish muscle undergo hydrolysis, resulting in the release of fatty acids. This is also supported by Okeyo et al. (2009), who stated that the accumulation of FFA could be due to lipases and phospho-lipase activity in digestive organs in muscle of Nile perch.

\begin{tabular}{|c|c|c|c|c|c|c|c|}
\hline Days & $\begin{array}{c}\text { Total } \\
\text { Protein } \\
(\%)\end{array}$ & $\begin{array}{c}\text { Total } \\
\text { Lipid (\%) }\end{array}$ & $\begin{array}{c}\text { Moisture } \\
(\%)\end{array}$ & Ash (\%) & FFA(\%) & pH & $\begin{array}{c}\text { TPC(log } \\
\text { (\%u/g) }\end{array}$ \\
\hline 0 & $18.01 \pm 0.06^{\mathrm{a}}$ & $4.84 \pm 0.2^{\mathrm{a}}$ & $88.64 \pm 0.1^{\mathrm{a}}$ & $1.49 \pm 0.09^{\mathrm{a}}$ & $0.5 \pm 0.01^{\mathrm{a}}$ & $6.8^{\mathrm{a}}$ & $2.74 \pm 0.2^{\mathrm{a}}$ \\
\hline 7 & $15.97 \pm 0.02^{\mathrm{b}}$ & $3.03 \pm 0.25^{\mathrm{b}}$ & $83.02 \pm 0.015^{\mathrm{b}}$ & $1.12 \pm 0.025^{\mathrm{b}}$ & $4.89 \pm 0.04^{\mathrm{b}}$ & $7.0^{\mathrm{b}}$ & $6.04 \pm 0.11^{\mathrm{b}}$ \\
\hline 14 & $11.93 \pm 0.03^{\mathrm{c}}$ & $1.95 \pm 0.02^{\mathrm{c}}$ & $80.81 \pm 0.09^{\mathrm{c}}$ & $1.04 \pm 0.04^{\mathrm{c}}$ & $8.17 \pm 0.7^{\mathrm{c}}$ & $7.2^{\mathrm{c}}$ & $7.30 \pm 0.07^{\mathrm{c}}$ \\
\hline 21 & $8.22 \pm 0.2^{\mathrm{d}}$ & $0.84 \pm 0.04^{\mathrm{d}}$ & $78.92 \pm 0.02^{\mathrm{d}}$ & $0.91 \pm 0.03^{\mathrm{d}}$ & $12.27 \pm 0.01^{\mathrm{d}}$ & $7.4^{\mathrm{d}}$ & $9.90 \pm 0.02^{\mathrm{d}}$ \\
\hline
\end{tabular}

Table: 1 Changes in raw muscle of Mystus seenghala stored under chilled condition at $4 \pm 1^{0} \mathrm{C}$.

\begin{tabular}{|l|c|c|c|c|c|c|c|}
\hline Days & $\begin{array}{c}\text { Total } \\
\text { Protein (\%) }\end{array}$ & $\begin{array}{c}\text { Total } \\
\text { Lipid (\%) }^{\text {(\%) }}\end{array}$ & Moisture (\%) & Ash (\%) & FFA(\%) & pH & $\begin{array}{c}\text { TPC(log10 } \\
\text { cfu/g) }\end{array}$ \\
\hline 0 & $18.81 \pm 0.06^{\mathrm{a}}$ & $4.94 \pm 0.03^{\mathrm{a}}$ & $88.04 \pm 0.04^{\mathrm{a}}$ & $1.51 \pm 0.07^{\mathrm{a}}$ & $0.57 \pm 0.02^{\mathrm{a}}$ & $6.8^{\mathrm{a}}$ & $2.70 \pm 0.09^{\mathrm{a}}$ \\
\hline 7 & $17.02 \pm 0.02^{\mathrm{b}}$ & $3.83 \pm 0.1^{\mathrm{b}}$ & $86.82 \pm 0.1^{\mathrm{b}}$ & $1.30 \pm 0.1^{\mathrm{b}}$ & $1.52 \pm 0.13^{\mathrm{b}}$ & $6.9^{\mathrm{b}}$ & $4.30 \pm 0.11^{\mathrm{b}}$ \\
\hline 14 & $15.78 \pm 0.03^{\mathrm{c}}$ & $2.74 \pm 0.11^{\mathrm{c}}$ & $85.07 \pm 0.7^{\mathrm{c}}$ & $1.12 \pm 0.74^{\mathrm{c}}$ & $2.32 \pm 0.03^{\mathrm{c}}$ & $7.0^{\mathrm{c}}$ & $5.78 \pm 0.2^{\mathrm{c}}$ \\
\hline 21 & $14.54 \pm 0.04^{\mathrm{d}}$ & $2.14 \pm 0.06^{\mathrm{d}}$ & $83.73 \pm 0.07^{\mathrm{d}}$ & $1 \pm 0.02^{\mathrm{d}}$ & $5.61 \pm 0.05^{\mathrm{d}}$ & $7.2^{\mathrm{d}}$ & $7.77 \pm 0.1^{\mathrm{d}}$ \\
\hline
\end{tabular}

Table: 2 Changes in raw muscle of Mystus seenghala stored under frozen condition at $-12 \pm 2^{0} \mathrm{C}$. - Mean \pm SD with different superscript in a row differs significantly $(\mathrm{P}<0.05)$.

3.6. $\mathrm{pH}$

In present studies, fish muscle that was stored in chiller $\left(4 \pm 1^{\circ} \mathrm{C}\right)$ showed rapid increase in $\mathrm{pH}$, while when in freezer $\left(-12 \pm 2^{\circ} \mathrm{C}\right)$, there was comparatively slow increase in $\mathrm{pH}$. It increased from 6.8 to 7.4 in chilled 
sample and from 6.8 to 7.1 in frozen sample during 21 days. These results are in line with those of Kandeepan and Biswas (2007) while conducting experiment on chilled and frozen buffalo meat. Erkan and Ozden (2008) stated that the increase was due to an increase in volatile bases from the decomposition of nitrogenous compounds by endogenous or microbial enzymes. Obemeata et al. (2011) observed that the increase in $\mathrm{pH}$ was higher in the $4^{\circ} \mathrm{C}$ stored sample of fish-Tilapia, than in the $-18{ }^{\circ} \mathrm{C}$ stored samples, indicating that biochemical and microbial changes are occurring faster in the fish of $4^{\circ} \mathrm{C}$ stored fish.

\subsection{Total Plate Count (TPC)}

As recommended by International Commission on Microbiological Specification for Food, ICMSF, (1986), an increase of total plate count (TPC) up to levels exceeding the value of $6 \log \mathbf{C F U} / \mathbf{g}$ is regarded as microbial spoiled fish muscle not fit for human consumption. In present investigation at $4 \pm 1^{0} \mathrm{C}$, the bacterial load in raw fish muscle for period of 21 days showed considerable increase. The TPC in raw fish muscle on day zero was rather low i.e. $2.74 \pm 0.2 \log$ cfu/g and on $21^{\text {st }}$ day of storage, it was increased further to the final value of $9.90 \pm 0.02 \log \mathrm{cfu} / \mathrm{g}$. At $-12 \pm 2^{\circ} \mathrm{C}$, the TPC in fish muscle on day 0 was found to be low in $2.70 \pm 0.09 \log \mathrm{cfu} / \mathrm{g}$ and at the end of storage i.e. $21^{\text {st }}$ day, it was found to be $7.77 \pm 0.2 \mathrm{log} \mathrm{cfu} / \mathrm{g}$. In present investigation, it was clearly depicted that the microbial growth was more rapid with increasing storage temperature. It has been reported that at $-12 \pm 2^{0} \mathrm{C}$, the TPC (5.78 $\left.\log \mathrm{cfu} / \mathrm{g}\right)$ was found to be within the permissible limit on 14th day of storage whereas at $4 \pm 1^{0} \mathrm{C}$, the TPC $(6.04 \log \mathrm{cfu} / \mathrm{g}) \mathrm{crossed}$ the permissible limit on 7th day of storage. Lawire (1998) attributed the microbial growth to the growth promoting effect of moisture on microbes in meat stored in chiller. Bao et al. (2007) reported a faster microbial growth in chilled than in superchilled samples of Arctic Charr fillet under the effect of dry ice and superchilling. Liu et al. (2010) reported increase in mesophilic bacterial load was found to be $85 \%$ in tray packed tilapia fillets stored at $0^{\circ} \mathrm{C}$. They calculate initial load of 3-4 log CFU/G/g, reaching $7.4 \log$ CFU/G/g on day 13.Obemeata et al. (2011) showed an increase in bacterial count from $7.9 \times 10^{3}$ to $7.6 \times 10^{7} \mathrm{cfu} / \mathrm{g}$ when Tilapia fish was stored at $4^{0} \mathrm{C}$ and from $7.9 \times 10^{3}$ to $5.4 \times 10^{1} \mathrm{cfu} / \mathrm{g}$ when Tilapia was stored at $-18^{0} \mathrm{C}$. They stated that freezing of fish at $-18^{0} \mathrm{C}$ created an unfavourable environmental condition for the growth and the survival of the micro-organisms, while freezing at $4^{0} \mathrm{C}$ allows the rapid proliferation of the micro-organisms.

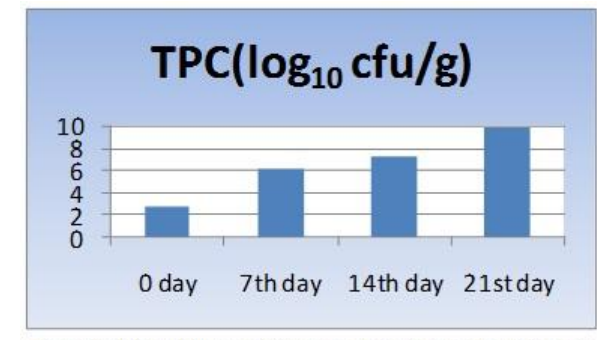

Figure 3: Bacteriological Changes of Raw Muscle of Mystus seenghala During Chilled Storage at $4 \pm 1^{\circ} \mathrm{C}$.

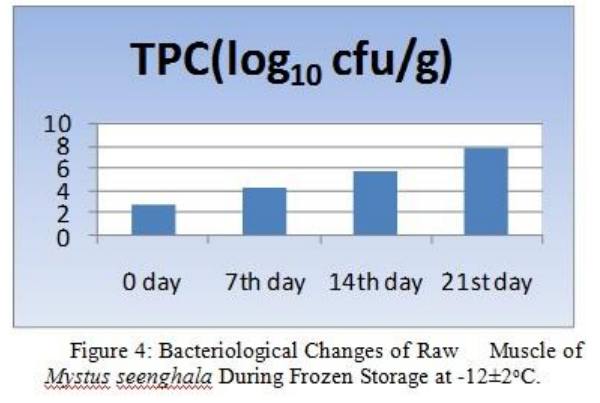

Mystus seenghala During Frozen Storage at $-12 \pm 2^{\circ} \mathrm{C}$.

\section{Conclusion}

Freezing of fish muscle at $-12 \pm 2^{\circ} \mathrm{C}$ causes comparatively lesser spoilage than chilling at $4 \pm 1^{\circ} \mathrm{C}$. This study reveals that as the storage period increases, there occurs degrading changes in biochemical and bacteriological composition that has direct effect on shelf life and market value of the fish. Freezing of fish creates unfavourable environmental conditions which slow down the bacterial growth and biochemical decomposition of fish muscle, thereby increasing the shelf life; while chilling at $4 \pm 1^{\circ} \mathrm{C}$ allows the comparatively rapid proliferation of bacteria, protein denaturation, lipid hydrolysis and oxidation; thereby reducing the shelf life. Hence, for storage purposes freezing is recommended, since frozen fish muscle will have the enhanced shelf life.

\section{References:}

[1] Agnihotri, M.K. (1988). A comparative study on shelf life and microbial spoilage of refrigerated buffalo meat. Ph.D. Thesis submitted to INRI, Izatnagar.

[2] APHA (1984). Compendium of method of microbiological examination of foods. 2nd Edn., American Public Health Association, Washington DC.

[3] Arannilewa, S.T., Salawu, S.O., Sorungbe, A.A. and Ola-Salawu, B.B. (2005). Effect of frozen period on the chemical, microbiological and sensory quality of frozen, tilapia fish (Sarotherodun galiaenus). African Journal of Biotechnology, 4 (8): $852-855$.

[4] Bao, H. N. D., Arason, S., Anna, K., I_'orarinsd'ottir (2007). Effects of Dry Ice and Superchilling on Quality and Shelf Life of Arctic Charr (Salvelinus alpinus) Fillets; International Journal of Food Engineering: 3(3)/7: 1-27.

[5] Erkan, N. and Ozden, O. (2008). Quality assessment of whole and gutted sardines (Sardina pilchardus) stored in ice. Int. J. Food Sci., 1549-1555.

[6] Folch, J., Less, M. and Sloane, G.W.S. (1957). A Simple Method For The Isolation And Purification Of Total Lipids From Animal Tissues. J. Biol. Chem. 226, 497-509. 
[7] International Commission on Microbiological Specifications for Foods (ICMSF), (1986). Sampling plans for fish and shellfish, In: Microorganisms in Foods. Sampling for Microbiological Analysis: Principles and Scientific Applications, 2(2) University of Toronto Press, Toronto, Canada, pp. 181-196.

[8] Kandeepan, G. and Biswas S. (2007). Effect of low temperature preservation on quality and shelf life of buffalo meat. Am. J. Food Technol., 2: 126-135.

[9] Keller, J. E., Kelly, G. C. and Acton, J. C. (1974). Effect of meat particle size and casing diameter on summer sausage properties during drying. Journal of Milk Food Technol., 37: 101-106.

[10] Kirschnik, P.G., Viegas, E. M. M. and Valenti, W.C. (2006). Shelf-Life of Tail Meat of the Giant River Prawn, Macrobrachium rosenbergii, Stored on Ice Journal of Aquatic Food Product Technology, 15(2).

[11] Kolodzicjska, I., Sikorski, Z.E. and Sandowska, M. (1987).Texture of Cooked Mantle of Squid Illexargentius as Influenced by Specimen Characteristics and Treatments. J. Food Sci. 52(4): 932-935.

[12] Koniecko, E. K. (1979). In: Handbook for meat chemists. Avery Publishing group Inc., Wayne, New Jersey, USA.

[13] Lawrie, R.A. (1998). The storage and preservationof meat II. Moisture control. In:Lawrie's Meat Science, $6^{\text {th }}$ Edn.:191-194.

[14] Liu, S., Fan, W., Zhong, S., Ma, C., Li, P., Zhou, K., Peng, Z. and Zhu, M., (2010). Quality evaluation of tray-packed tilapia fillets stored at $0^{\circ} \mathrm{C}$ based on sensory, microbiological, biochemical and physical attributes. African Journal of Biotechnology; 9(5), 692-701.

[15] Lowry, O.H., Rosenbrough, N.J., Farr, A.L. and Randall, R.J. (1951). Protein measurement with the folin phenol reagent. J. Biol. Chem., 193: 265-275.

[16] Obemeata, O., Nnenna, F.P. and Christopher, N. (2011) Mobiological assessment of stored Tilapia guineesis. Afric. J.Food Sci. 5(4):242-247

[17] Pacheco-Aguilar, R., Lugo-Sanchez, M. E. and Robles-Burgueno, M. R. (2000). Postmortem biochemical characteristic of Monterey sardine muscle stored at $0^{\circ} \mathrm{C}$. J Food Sci., 65: 40-47.

[18] Siddiqui, M.R. and Ali, M. (1979). Effect of ice storage prior to freezing on the quality of frozen shrimp. Pak. J. Sci. Ind. Res., 6(22): 327

[19] Siddique, M.N., Hasan,M.J., Reza, M.Z., Islam,M.R., Boduruzaman M., Forhadur, M. and Reza, S. (2011). Effect of freezing time on nutritional value of Jatpunti (Puntius sophore), Sarpunti (P. sarana) and Thaisarpunti (P. gonionotus). Bangladesh Research Publications Journal 5(4): 387-392.

[20] Zamir, M., Qasim, R. and Ullah, A. (1998). Changes in physical and chemical constituents of crab meat during storage at refrigerator temperature $\left(7 \pm 2^{\circ} \mathrm{C}\right)$. Pak. J. of Pharma. Sci. 11(1): 27-33. 